УДК 343.1

\title{
Н.O. Машинникова
}

\section{ЗЛОУПОТРЕБЛЕНИЕ ПРАВОМ И СУДЕБНЫЕ ОШИБКИ В УГОЛОВНОМ СУДОПРОИЗВОДСТВЕ, ПРИЧИНЫ ИХ СОВЕРШЕНИЯ ПРИ РАССМОТРЕНИИ УГОЛОВНЫХ ДЕЛ ПРИ СОГЛАСИИ ОБВИНЯЕМОГО С ПРЕДЬЯВЛЕННЫМ ЕМУ ОБВИНЕНИЕМ}

В статье исследуются категории «злоупотребление правом» и «судебная ошибка», а также факторы, способствующие их возникновению, раскрывается механизм возникновения судебных ошибок, указываются источники и причины их возникновения. Утверждается, что судья является самостоятельным заинтересованным лицом в уголовном судопроизводстве. Замещение профессионального интереса при разрешении судьёй уголовного дела по существу любым иным будет препятствовать достижению целей правосудия. Обосновывается утверждение о том, что дефект заинтересованности судьи как аспект правоприменительной деятельности обусловливает возникновение злоупотреблений и может стать причиной судебной ошибки. Выявлены основные характеристики судебной ошибки, а также признаки, отличающие судебную ошибку от злоупотребления. В статье дано определение понятия «злоупотребление правом», выявлены его свойства и особенности. Исследуются причины судебных ошибок по уголовным делам при согласии обвиняемого с предъявленным ему обвинение. Анализируются особенности совершения судебных ошибок и злоупотреблений при рассмотрении уголовных дел в порядке главы 40 УПК РФ.

Ключевые слова: особый порядок судебного разбирательства, усмотрительная деятельность, внутреннее убеждение, истина, судебная ошибка, злоупотребление правом, заинтересованность, уголовное судопроизводство, глава 40 УПК РФ.

DOI: $10.35634 / 2412-9593-2021-31-3-459-472$

Правосудие является ключевой формой правоприменения в любом государстве. Его цель - устранение социально-правовых конфликтов, многие из которых являются следствием ранее совершённых правоприменительных ошибок и злоупотреблений. Суду как субъекту правоприменительной деятельности такие дефекты также свойственны. Наибольший вред основным правам и свободам человека наносят судебные ошибки и злоупотребления, допущенные в уголовном судопроизводстве. И судебные ошибки, и злоупотребление правом снижают эффективность судебной власти и уровень доверия к ней, затрудняют разрешение социально-правовых конфликтов.

При осуществлении правосудия целеполагание судьи должно соответствовать ст. 6 УПК РФ. Задачей правосудия является постановление законного, обоснованного и справедливого приговора вследствие разрешения уголовно-правового конфликта, при постановлении которого судья должен быть беспристрастен. В Толковом словаре В. Даля беспристрастность определяется как отсутствие пристрастности (приверженности) к той либо другой стороне ${ }^{1}$, что предполагает отсутствие у судьи заинтересованности в исходе дела в пользу одной из сторон. Между тем указанная задача опосредуется внутренними качествами правоприменителя, его потребностями и направленностью личности. Кроме того, при постановлении любого приговора судья вынужден учитывать существенное количество разнообразных внешних факторов, не имеющих отношения к событию преступления, пренебрежение которыми впоследствии может негативно сказаться как на принятом решении, так и на том, кто его принял. К таким факторам можно отнести следующие: корпоративный (ведомственный) интерес, большая индивидуальная нагрузка, общественный и государственный интерес, политический резонанс, экономическая ситуации и др. При этом осуществление правосудия должно обусловливаться только профессиональным интересом. Отсутствие у судьи профессиональной заинтересованности в качественном рассмотрении уголовного дела является причиной возникновения судебных ошибок. Как верно отвечает С.А. Пашин, «... самое важное в суде - это правосудие, а не покорность. Судьи не должны быть чиновниками, так как правосудие - это служение» ${ }^{2}$. Изменение направленности этой

\footnotetext{
${ }^{1}$ Толковый словарь живого великорусского языка В. Даля: в 4 т. М., 1956. Т.1. С. 72-73.

${ }^{2}$ Пашин С. Комментарий информационному порталу zasudili.ru от 08.05.2019 г. URL: http://zasudili.ru/news/ 9387/?fbclid=IwAR3ElZoBpZYPFdyJAKITjks29KsyrFVI5RnBjukODmLw5USDfPC1qWv9dLU
} 
заинтересованности с профессиональной на охранительную либо личную обусловливает возникновение процессуальных злоупотреблений со их стороны. Так, по справедливому мнению А.К. Большакова, «судья плох, если ему безразлично, что будет с вынесенным им решением. Каждый специалист должен ответственно относиться к результатам своего труда». Далее он указывает на то, что «имеет место диссонанс между задачами уголовного судопроизводства (ст. 6 УПК РФ) и принципом состязательности (ст. 15 УПК РФ)» и делает вывод, что положения закона (о состязательности. - nрим. М.H.) рассчитаны на идеальное применение, которое в действительности далеко от идеала ${ }^{3}$. Полагаем, что необходимо признать факт заинтересованности судьи в результате судопроизводства по каждому находящемуся у него в производстве делу. Для целей уголовного судопроизводства предлагаем под заинтересованностью суда, в контексте постановления приговора, понимать мотивацию судьи (её качества и первопричины) к разрешению дела по существу. Когда направленность заинтересованности смещается от заданного вектора в любую другую сторону, осуществляемое судьёй судебное разбирательство не будет отвечать целям правосудия. Судья при таких обстоятельствах мотивирован не желанием постановить законный, обоснованный и справедливый приговор, руководствуясь совестью и законом, а принять по делу такое решение, которое бы в наименьшей степени могло повлечь для него негативные последствия (охранительный интерес), либо, если речь идёт о коррупции как крайней форме злоупотребления, постановить по делу такой приговор, который необходим его заказчику.

Дефект заинтересованности судьи (как аспект его усмотрительной деятельности) при осуществлении им правосудия обусловливает возникновение злоупотреблений и может стать причиной судебных ошибок.

В Толковом словаре Д.Н. Ушакова под злоупотреблением понимается проступок, преступление, состоящее в сознательном, незаконном и корыстном использовании своих возможностей и прав во вред другим ${ }^{4}$. Аналогичное определение злоупотребления можно встретить в Словаре русского языка С.И. Ожегова 5 . Толковый словарь В. Даля определяет глагол «злоупотреблять» как употреблять во зло, на худое дело, обращать хорошее средство на худое дело ${ }^{6}$.

В науке злоупотребление правом исследуется с разных сторон: 1) как правовая категория; 2) как явление правовой действительности и 3) как юридический феномен. Как справедливо отмечает О.Н. Бармина, злоупотребление правом представляет собой такое негативное явление правовой природы общественных отношений, при которых субъект, реализуя своё право (права), вступает в конфликт с высшими ценностями и идеалами права ${ }^{7}$.

Злоупотребление правом «является межотраслевой категорией, проявляющей себя и в тех общественных отношениях, которые урегулированы нормами публичного права» ${ }^{8}$. Часть 3 статьи 17 Конституции РФ указывает на недопустимость злоупотребление правом: «Осуществление прав и свобод человека и гражданина не должно нарушать права и свободы других лиц».

Российский законодатель с осторожностью использует термин «злоупотребление» и не даёт его нормативного определения. Вопрос злоупотребления правом достаточно глубоко исследован в науке гражданского права, в ходе исторического развития которой сформировалась такая конструкция, как «злоупотребление правом» - «шикана». Под злоупотреблением правом в гражданском праве понимается действие / бездействие, состоящее в использовании своего субъективного права, данного в силу закона либо договора, с целью причинить вред другому лицу. В соответствии с ч. 1 ст. 10 ГК РФ не допускается осуществление гражданских прав исключительно с намерением причинить вред другому лицу, действия в обход закона с противоправной целью, а также иное заведомо недобросовестное осуществление гражданских прав (злоупотребление правом).

\footnotetext{
${ }^{3}$ Интервью И. Рамазанова с А.К. Большаковым, Судья, заинтересованный в правосудном решении // Электронный журнал «Уголовный процесс». 2017. № 7. URL: https://e.ugpr.ru/article.aspx?aid=566547\&token=1104a797bcaa-11a0-4d55-2d01b79d2008\&ttl=7888\&ustp=W

${ }^{4}$ Толковый словарь под ред. Д.Н. Ушакова. URL: https://dic.academic.ru/dic.nsf/ushakov/817386

${ }^{5}$ Толковый словарь под ред. С.И. Ожегова, Н.Ю. Шведовой. URL: https://dic.academic.ru/dic.nsf/ogegova/69102

${ }^{6}$ Толковый словарь живого великорусского языка В. Даля: в 4 т. М., 1956. Т. 1. С. 685.

${ }^{7}$ Бармина О.Н. О злоупотреблении правом //Право. 2011. С. 109.

${ }^{8}$ Пономарев В.Г. О сущности злоупотребления правом и его месте в уголовном законодательстве Российской Федерации // Вестник Волгоградского государственного университета. Сер. 5: Юриспруденция. 2012. № 1. C. $158-167$.
} 
Злоупотребление правом и судебные ошибки в уголовном судопроизводстве...

461

ЭКОНОМИКА И ПРАВО

2021. Т. 31, вып. 3

Российскому уголовному праву известно понятие «злоупотребление», совершаемое в двух формах:

1) злоупотребление доверием;

2) злоупотребление полномочиями.

Злоупотребление доверием характеризуется использованием с корыстной целью доверительных отношений. Для злоупотребления полномочиями характерно использование своих полномочий вопреки интересам другого лица либо интересам службы с корыстной целью, либо в силу иной личной заинтересованности.

В сферу научных интересов уголовного процесса вопрос «злоупотребления» попал относительно недавно. Однако УПК РФ указанного термина не содержит. Применительно к нему категорию «злоупотребление» целесообразно рассматривать как негативную черту процессуальной правоприменительной деятельности, включающую в себя как злоупотребление правом, так и злоупотребление полномочиями. Осуществление правосудия является процессуальной деятельностью, осуществляемой в рамках, предоставленных субъекту полномочий. Под полномочиями понимается совокупность прав и обязанностей, которыми наделяется субъект для осуществления деятельности. Обязанностью как мерой должного поведения субъекта злоупотреблять невозможно. Следовательно, и при злоупотреблении правом, и при злоупотреблении полномочиями, применительно к процессуальной деятельности, понимается всегда злоупотребление именно правом. Таким образом, термины «злоупотребление правом» и «злоупотребление полномочиями» целесообразно рассматривать как синонимы.

3 февраля 2015 г. Верховный Суд РФ дал следующее разъяснение: «Злоупотребление правом имеет место в случае, когда субъект поступает вопреки норме, предоставляющей ему соответствующее право, не соотносит поведение с интересами общества и государства, не исполняет корреспондирующую данному праву юридическую обязанность» ${ }^{9}$. Однако ясности с точки зрения уголовного процесса в части злоупотребления правом настоящее определение не внесло. Очевидно, что злоупотребление правом формально является поведением правовым, но недопустимым с точки зрения морально-этической.

О недопустимости злоупотребления предоставленными правами говорится в ч. 2 ст. 29 Всеобщей декларации прав человека; ч. 2 ст. 22 Международного пакта о гражданских и политических правах; ст. 6 и 35 Европейской конвенции о защите прав и основных свобод.

Обратимся к толкованию понятия «злоупотребление правом»:

По мнению А.А. Малиновского, «злоупотребление правом - есть такая форма реализации права в противоречии с назначением, посредством которой субъект причиняет вред другим участникам правоотношений» ${ }^{10}$. Исследуя философские и правовые концепции понятия злоупотребления правом, О.Н. Бармина указывает, что злоупотреблением может считаться только то осуществление права управомоченным субъектом, которое характеризуется злостностью, определяемой через социальную вредность поведения, обусловленную корыстной или иной личной заинтересованностью, эгоистическим воплощением в процесс осуществления права только своих интересов. Далее она обозначает разницу между злоупотреблением правом и правонарушением, отмечая, что при вредоносном злоупотреблении правом мы можем иметь дело с нарушением законных интересов других лиц, тогда как при правонарушении закон не требует такого признака ${ }^{11}$.

В.И. Гойман определяет злоупотребление правом как «основанное на эгоистических побуждениях поведение управомоченного субъекта, противоречащее природе права, закреплённой в его нормах цели, либо связанное с привлечением неправовых средств для её достижения» ${ }^{12}$. С данным утверждением согласиться нельзя, поскольку процесс злоупотребления правом происходит в правовом поле путём использования правовых средств в целях получить личную выгоду, снизить издержки (риски) либо причинить вред другому лицу.

\footnotetext{
${ }^{9}$ Определение Верховного Суда РФ по делу № 32-КГ14-17 от 03.02.2015 г. URL:http://www.consultant.ru/

${ }^{10}$ Герасимова О., Малиновский А. Злоупотребление права. Правосудие в Восточной Сибири. 2003. № 3 (10-11).

URL: http://www.law.edu.ru/doc/document.asp?docID=1135116

${ }^{11}$ Бармина О.Н. Злоупотребление правом / под ред. В.А. Колодова, Киров: Радуга-ПРЕCC, 2015. URL: http://www.consultant.ru

${ }^{12}$ Гойман В.И. Правонарушение и юридическая ответственность. Общая теория государства и права: учебник. M., 2002. C. 288.
} 
Как справедливо отмечает М.В. Новиков, для установления факта злоупотребления правом «установления одной причинно-следственной связи недостаточно... Здесь необходимо ещё проводить причинно-интенциональную связь между формально основанными на законе действиями (бездействием) и недобросовестными намерениями лица» ${ }^{13}$.

Источником злоупотребления правом служат относительно определённые нормы, которые предоставляют правоприменителю полномочие действовать в их пределах по собственному усмотрению. Одновременно эти же относительно определённые нормы являются и средством злоупотребления правом, поскольку именно их использование с недобросовестными намерениями и представляет собой злоупотребление правом.

Злоупотребление правом является волевым осознанным актом правоприменителя, совершённым им в правовых пределах, но не отвечающим нормам этики и морали. Главным свойством злоупотребления правом является его «намеренность». Особенностью злоупотребления правом, является то, что, нарушая чужие законные интересы, правоприменитель пользуется предоставленными ему правами, не выходя за их пределы. Злоупотребление правом применительно к осуществлению правосудия всегда ограничено нормами процессуального права. Злоупотребление правом как негативная форма проявления судебного усмотрения находит своё выражение в двух формах: судебный произвол и коррупция.

Нормативное определение термину «коррупция» дано в п. 1 ст. 1 Федерального закона от 25.08.2008 г. № 273-Ф3 «О противодействии коррупции». Однако понятие «судебный произвол» нормативно не закреплено. Предметом самостоятельного теоретического исследования понятие судебного произвола также не являлось. Между тем, изучая вопросы судейского усмотрения и его пределов, А.А. Хайдаров обоснованно пришёл к выводу, что судебный произвол представляет собой осознанно принимаемые по судейскому (судебному) усмотрению процессуальные решения или совершаемые процессуальные действия, которые ущемляют права и законные интересы участников уголовного процесса со стороны обвинения и (или) защиты, а также противоречит назначению уголовного судопроизводства ${ }^{14}$.

Понятие ошибки существенно шире понятия злоупотребления. Оно применимо к целому классу понятий, связанных с искажением, с дефектом деятельности в каждом из трёх полей: предметном, логическом и смысловом ${ }^{15}$. При этом ошибка, в отличие от злоупотребления, имеет двойственную природу, поскольку представляет собой не только действие, но и его последствия. Французский математик Э. Борель писал, что «человек, который ошибается, является вдвойне незнающим: он не знает точного ответа, и он не знает, что он его не знает. Именно это второе незнание опасно, так как внутренняя уверенность ошибающегося, что он даёт правильный ответ, совершенно такова, как и уверенность того, кто знает и не ошибается» ${ }^{16}$. Э.Ч. Хьюз рассматривал ошибки и неудачи в работе как неизбежный компонент любого рода занятий и профессий, влияющий на их функционирование в широком социальном контексте ${ }^{17}$.

Теория деятельности определяет ошибку как факт практики. Вероятность совершения ошибки зависит от сложности поставленной трудовой задачи: чем сложнее поставленная задача, тем больше вероятность совершения ошибки. Ошибка непосредственно связана с познанием, а также с выбором субъекта и ответственностью за него.

Основная идея, связанная с объяснением причин ошибочных действий, включает в себя гипотезу о существовании скрытых, непознаваемых механизмов работы психического аппарата, которые подготавливают те или иные действия субъекта, включая ошибочные ${ }^{18}$. Феноменологию ошибок рас-

\footnotetext{
${ }^{13}$ Новиков М.В. Механизм злоупотребления правом. Пробелы в российском законодательстве. 2016. № 8. С. 134.

${ }^{14}$ Хайдаров А.А., Судейское усмотрение и его пределы в судебных стадиях уголовного процесса России: автореф. дис. ... канд. юрид. наук. М., 2011. С. 7.

${ }^{15}$ Батурина О.С. Концепт «ошибка»: психологический смысл // Психологическое сопровождение личности в кризисных ситуациях: материалы Республиканской науч.-практ. конф., г. Уфа, 26.04.2012. С. 21.

${ }^{16}$ Борель Э. Вероятность и достоверность, М., 1969.

${ }^{17}$ Hughes E.C. Mistakes at Work // The Canadian Journal of Economics and Political Science. 1951. Vol. XVII. P. 320-327.

${ }^{18}$ Агафонов А.Ю. Сознание: где искать «чёрный ящик»? // Методология и история психологии. 2009. Вып. 1. T. 4. C. 151-165.
} 
Злоупотребление правом и судебные ошибки в уголовном судопроизводстве...

463

крыл 3. Фрейд путём изучения и систематизации опытов сновидений и процедур свободного ассоциирования пациентов. Основой теории служит представление о взаимодействии осознаваемых и неосознаваемых сфер психики индивида. Он предположил наличие механизма, осуществляющего деятельность по анализу информации, хранящейся в памяти субъекта на предмет соответствия этой информации с предрасположенностями данного субъекта ${ }^{19}$.

В теории психологии А.Ю. Агафонов, Е.М. Гришакова и Е.А. Найдич предлагают следующую классификацию ошибок:

- когнитивные ошибки, возникающие в результате познавательной деятельности;

- ошибки социальной коммуникации как результата социального влияния и социальной перцепции;

- ошибки морального выбора ${ }^{20}$.

При этом А.Ю. Агафонов признает, что бессознательная сфера психики также может допускать ошибки (ошибка неосознанной деятельности), это свидетельство того, что предпосылка ошибки может быть подготовлена до её осознания и совершения субъектом. Кроме того, автор обращает внимание на то, что указанная сфера психики не может исправлять допущенные ей ошибки без их осознания $^{21}$. Логично предположить, что осознавать субъекту для исправления допущенной ошибки необходимо результаты своих действий. Данный эффект в теории психологии принято называть «обратной связью».

В Толковом словаре В. Даля под ошибкой понимается неумышленный проступок или невольное, ненамеренное искажение чего-либо ${ }^{22}$. Термин «ошибка» не нашёл своего закрепления ни в уголовном, ни в уголовно-процессуальном законе. Юридический словарь раскрывает понятие «ошибка» как неправильное представление лица о юридических или фактических свойствах и последствиях совершаемых им действий ${ }^{23}$.

В юридической науке различают юридическую и фактическую ошибки. К юридическим относят ошибки, связанные с применением правовых норм.

К юридическим ошибкам В.Н. Карташов относит дефекты (погрешности, недостатки, изъяны) в профессиональной юридической деятельности, носящие непреднамеренный характер, связанные с отрицательными последствиями и требующие определённых мер социально-правовой защиты участников правовой деятельности ${ }^{24}$.

Фактические ошибки относятся к обстоятельствам объективной действительности. Как верно указывает А.А. Аубакирова, рассматривая ошибки, совершаемые в судопроизводстве, следует обратить внимание на очень существенное обстоятельство: различие ошибок мысли (восприятия, оценки, понимания) и ошибок действия (поступков, решений, воздействия на кого-либо, что-либо $)^{25}$. Последствия ошибки в юриспруденции переоценить сложно, особенно, если речь идет о судебной ошибке. По мнению 3.Ф. Ковриги, судебная ошибка - это «непреднамеренное искаженное познание объективной действительности» ${ }^{26}$. В любом случае судебная ошибка является дефектом внутреннего убеждения. Исключение составляют тактические ошибки при решении о совершении определённых процессуальных действий (о допросе свидетеля, о назначении экспертизы и др.).

Можно долго дискутировать о праве судьи на ошибку. Однако ни ранее, ни в настоящее время такого права в законодательстве закреплено не было. Между тем практика судебных ошибок существует, и каждая такая ошибка причиняет кому-то вред. Как справедливо отмечал М.С. Строгович, «право на ошибку ниоткуда не вытекает, ни в юридическом, ни в этическом отношении. Судебные ошибки были, имеются сейчас и с их возможностью приходится считаться в будущем. Но права су-

\footnotetext{
${ }^{19}$ Фрейд 3. Толкование сновидений, М., 2011. С. 82-83.

${ }^{20}$ Агафонов А.Ю., Гришакова Е.М., Найдич Е.А. Феноменология ошибочных действий: психоаналитический и когнитивный подходы // Известия Самарского научного центра РАН. 2012. Т. 14, № 2 (5). С. 1200-1203.

${ }^{21}$ Агафонов А.Ю. По обе стороны сознания. Экспериментальные исследования по когнитивной психологии. Самара, 2012. С. 56.

${ }^{22}$ Толковый словарь живого великорусского языка В. Даля: в 4 т. Москва, 1956. Т. 2 С. 622-623.

${ }^{23}$ Юридический словарь/ под ред. С.Н. Братуся. М., 1953. С. 433.

${ }^{24}$ Карташов В.Н. Профессиональная юридическая деятельность / ЯрГУ. Ярославль, 1992. С. 52.

${ }^{25}$ Аубакирова А.А. Гносеология судебной ошибки // Вестник ЮУрГУ. № 25. 2010. С. 20.

${ }^{26}$ Коврига 3.Ф. Уголовно-процессуальная ответственность. Воронеж, 1994. С. 63.
} 
дей на ошибку... не существует, такого права не было раньше, нет сейчас и не будет в дальнейшем. Судебная ошибка - это всегда нарушение законности» ${ }^{27}$.

Со своей стороны полагаем, что при формальном подходе судебная ошибка как вид правоприменительной ошибки представляет собой несоответствие признаков правосудия (как исключительного вида правоприменительной деятельности) его назначению, а конкретно ст. 6 УПК РФ. Правоприменение в рамках судопроизводства реализуется посредством применения процессуальных и материальных норм, в связи с чем деятельность правоприменителя оценивается на предмет соответствия указанным нормам. Действующий уголовно-процессуальный закон содержит достаточно большое количество относительно определённых норм, что предполагает осуществление деятельности правоприменителем не однонаправленно (императивно под влиянием внешнего принуждения), а в установленных законом правовых пределах усмотрительной деятельности. В данном случае именно выход за эти пределы будет являться судебной ошибкой. Как верно указывают А.В. Паркина и Н.И. Уздимаева, в ситуациях, когда правоприменитель может действовать по собственному усмотрению «... дополнительным критерием оценки правовой деятельности как ошибочной или безошибочной становится критерий целесообразности. Нецелесообразным при этом считается выбор любого, кроме оптимального варианта развития событий, или варианта, приводящего к отрицательным последствиям. Каким должно быть оптимальное решение - для каждой конкретной ситуации необходимо определять отдельно» ${ }^{28}$.

К.Р. Мурсалимов определяет судебную ошибку как ошибку в практической деятельности особого органа государства - суда, призванного осуществлять правосудие по уголовным и гражданским делам $^{29}$. М.Л. Голубевой разработано авторское определение судебной ошибки, под которой она понимает «непреднамеренное деяние (действие или бездействие) лица, осуществляющего рассмотрение уголовного дела в досудебных или судебных стадиях уголовного процесса, а также в стадии исполнения приговора, выразившееся в неправильном применении, несоблюдении требований уголовного, уголовно-процессуального закона, повлекшее существенное нарушение конституционных прав и свобод человека и гражданина ${ }^{30}$. Весьма точное определение судебной ошибки даёт А.А. Ширванов. По его мнению, «под ошибкой в уголовном судопроизводстве следует понимать формально не противоречащее нормам (норме) уголовно-процессуального права деяние, совершённое вследствие добросовестного заблуждения субъектом уголовно-процессуальных правоотношений в форме действия или бездействия в любой стадии уголовного судопроизводства, которое путём лишения или ограничения гарантированных законом прав участников уголовного судопроизводства или иным путём повлияло на законность, обоснованность или справедливость принимаемого по делу решения» ${ }^{31}$. Авторы обоснованно расширяют определение судебной ошибки за счёт бездействия, поскольку незаконное непреднамеренное бездействие судьи также может повлечь за собой впоследствии нарушение требований уголовнопроцессуального законодательства. Кроме того, они указывают на обязательные свойства судебной ошибки. В частности, авторы связывают ошибку с субъектом, который её генерирует; с применением уголовно-процессуальных норм; с выраженностью ошибки в процессуальных (официальных) действиях суда, которые в итоге объективизируются в итоговом решении по делу - приговоре.

На добросовестность как отличительную от злоупотребления черту судебной ошибки указывает Р.С. Белкин. По его мнению, «именно добросовестное заблуждение отличает ошибку в судопроизводстве от профессиональных упущений, нарушений, должностных проступков и даже преступлений против правосудия. Всякое заведомо неправильное действие, суждение, нарушение установленных норм закона не является ошибкой и требует иного, нежели на ошибку реагирования» ${ }^{32}$. Как отмечает

\footnotetext{
${ }^{27}$ Строгович М.С. Право обвиняемого на защиту и презумпция невиновности. М., 1984. С. 33.

28 Паркина А.В., Уздимаева Н.И. Правоприменительная ошибка: понятие и признаки. C. 2. URL: https://cyberleninka.ru/ article/n/pravoprimenitelnaya-oshibka-ponyatie-i-priznaki

${ }^{29}$ Мурсалимов К.Р. Правоприменительные ошибки. Проблемы теории: дис. ... канд. юрид. наук. Н. Новгород, 2000. C. 18.

${ }^{30}$ Голубева М.Н. Судебная ошибка: теоретико-прикладной анализ: автореф. дис. ...канд. юрид. наук. Н. Новгород, 2009. С. 10.

${ }^{31}$ Ширванов А.А. Понятие ошибки в уголовном судопроизводстве и её отличие от правонарушения // Российский следователь. 2005. № 7. С. 57.

32 Белкин Р.С. Криминалистика: проблемы сегодняшнего дня. Злободневные вопросы российской криминалистики. М., 2001. С. 166.
} 
Злоупотребление правом и судебные ошибки в уголовном судопроизводстве...

465

В.И. Фалеев, термин «судебная ошибка» - это «суждения, решения и действия суда, являющиеся результатом добросовестного заблуждения, несоответствующие объективной действительности и закону и поэтому не приводящие к целям судопроизводства. Данным понятием охватываются не только ошибки, допущенные судом... и влекущие отмену или изменение приговора, но и другие ошибки, совершение которых непосредственно таких последствий не влечёт» ${ }^{33}$.

Таким образом, судебная ошибка характеризуется следующими чертами: она всегда связана с внутренним убеждением и является его негативным продуктом. В отличие от злоупотребления, ошибка характеризуется неосознанностью (ненамеренностью) и добросовестностью её совершения. Ещё одним отличием судебной ошибки от злоупотребления правом является то, что судебная ошибка не ограничена нормами закона. Совершение судебной ошибки всегда влечёт за собой не только нарушение прав иных лиц, но и нарушение правовых норм. При этом необходимо иметь в виду, что при ошибке у правоприменителя первоначально всегда присутствует возможность сделать правильный выбор в пределах предоставленных ему полномочий.

Источником судебной ошибки являются несколько факторов:

1) неточно сформулированная правовая норма. Любая правовая норма - это продукт правотворческой деятельности, и от того, насколько корректно и безошибочно будет сформулирована правовая норма, зависит качество и эффективность правоприменительной деятельности;

2) неверно воспринятые, интерпретированные и оценённые фактические обстоятельства, которые являются предметом изучения по уголовному делу. Неверное установление логическосмысловой цепочки фактов и обстоятельств (причины, цели, мотивы, последствия);

3) поскольку судебное правоприменение в уголовном судопроизводстве всегда вторично по отношению к уже ранее применённым нормам права при возбуждении и расследовании уголовного дела, самостоятельным источником судебных ошибок является уже ранее совершённая иным должностным лицом правоприменительная ошибка.

На практике, как пишет С.А. Пашин, судебной ошибкой считается «несоответствие позиции судьи мнению вышестоящей инстанции, уклонение его от проводимой в регионе уголовной политики». Требования уголовной политики составляют основное содержание «установки», которая определяет судебную практику в гораздо большей степени, чем закон ${ }^{34}$. Очень интересную трактовку судебной ошибке даёт О.С. Сычёва, которая указывает, что в качестве судебной ошибки может быть убеждение судьи, скорректированное вышестоящей инстанцией ${ }^{35}$.

Приведённые трактовки судебных ошибок «ставят крест» на принципе независимости судей при осуществлении ими правосудия и подтверждают их зависимость от позиции суда вышестоящей инстанции. В России отсутствует единый нормативный критерий оценки качества работы судей, что является причиной воздействия на судью путём манипулирования практикой привлечения к дисциплинарной ответственности. По мнению В.Ф. Яковлева, качество судебной работы определяется... стабильностью судебных решений и степенью их отменяемости ${ }^{36}$. Согласно судебной статистике, стабильность судебных актов по уголовным делам за 2019 г. составила $97 \%$, что свидетельствует о том, что погрешность (ошибочность) судебных актов отечественного правосудия стремится к нулю. Однако так ли это на самом деле? Согласно этому же докладу, 55 \% от общего числа уголовных дел за 2019 г. были рассмотрены судами в особом порядке, то есть фактически при отсутствии спора по делу; без возможности постановления оправдательного приговора и при отсутствии права сторон обжаловать судебный акт по основанию несоответствия выводов суда материалам уголовного дела. В связи с чем используемая ВС РФ статистика не отражает действительного размера погрешности принимаемых судебных актов. В свою очередь приведённая статистика справедливо исходит из объективированного результата погрешности судебных актов, выраженного в количестве отменённых приговоров. Однако необходимо учитывать наличие латентных судебных ошибок и злоупотреблений, ко-

\footnotetext{
${ }^{33}$ Фалеев В.И. Уголовно-процессуальные аспекты выявления и устранения судебных ошибок: дис. ... канд. юрид. наук. Калининград, 2002. С. 10.

${ }^{34}$ Пашин С.А. Проблема судебной ошибки // Юридическая психология. 2007. № 2. URL: http://www.consultant.ru

${ }^{35}$ Сычёва О.А. Судебная ошибка в уголовном судопроизводстве // Симбирский научный вестник (Ульяновск). 2013. № 1 (11). С. 104-108.

${ }^{36}$ Яковлев В.Ф. Довести начатое до конца, добиться эффективной работы всей судебной системы // Вестник ВАС РФ. 2001. № 5 .
} 
торые не были выявлены судами вышестоящих инстанций в силу разных обстоятельств, в том числе и по причине необжалования приговора.

Злоупотребление правом и судебная ошибка являются дефектом правоприменительной деятельности при осуществлении правосудия и препятствуют достижению назначения уголовного судопроизводства, указанного в ст. 6 УПК РФ.

С учётом источника происхождения судебных ошибок, последние подразделяются по видовому признаку на:

- нарушение уголовно-процессуального закона;

- нарушение уголовного закона;

- организационно-тактические;

- организационно-технические;

- психологические;

- комплексные.

К ошибкам правоприменительной деятельности, в том числе и при осуществлении правосудия, относят ошибки толкования, доктринальные ошибки, правореализационные ошибки (неправильное использование и исполнение правовых норм). По виду правовых норм правоприменительные ошибки делятся на материальные и процессуальные.

При таком разнообразии психологических и юридических ошибок в правоприменительной деятельности появляется эффект, при котором одно и то же действие может быть как ошибочным, так и верным одновременно. Это зависит от позиции стороны, относительно которой устанавливается верность либо ошибочность действия. Решение, которое по внутреннему убеждению оценивается как верное, может быть воспринято ошибочным профессиональным сообществом либо общественностью. В частности, совершая ошибку мышления при оценке доказательств, судья может оказаться правым с точки зрения организационно-тактической деятельности и коммуникации.

А.В. Паркина и Н.И. Уздимаева полагают, что по психологическому механизму формирования можно различать ошибки умышленные и неумышленные, указывая на то, что умышленная ошибка является проявлением противоправности ${ }^{37}$. Мы не согласны с данной позицией авторов, поскольку ключевым свойством ошибки является неосознанность её совершения. Умысел представляет собой продуманный, осознанный, злонамеренный поступок, направленный во вред. Любое умышленное процессуальное действие, целью которого явилось искажение действительности, совершённое во вред социальным или правовым отношениям, является не ошибкой, а злоупотреблением. Любая ошибка порождается внутренним убеждением, основанным на неверных посылках и не является осознанной в момент её совершения. В свою очередь любая форма злоупотребления изначально обусловлена осознанной процессуальной деятельностью по усмотрению.

Совершение правоприменителем судебных ошибок зависит от совокупности объективных и субъективных факторов. Если субъективные факторы, оказывающие непосредственное влияние на внутреннее убеждение (направленность личности, его внутренние страхи и переживания, предубеждённость относительно явлений и др.) присутствуют в деятельности правоприменителя всегда, то заблуждение правоприменителя, обусловленное в большей мере объективными причинами, встречается не часто. Последнее возникает лишь тогда, когда правоприменитель, в силу независящих от него факторов, не мог либо не должен был их предвидеть.

Как справедливо отмечает В.А. Азаров, «не стоит забывать о том, что субъект, творящий правосудие, а именно - суд, неразрывно связан с таким человеческим фактором, как внутреннее убеждение, которое является весомой частью содержания понятия "судебная ошибка", при наличии таковой. Естественно полагать, что при рассмотрении каждого уголовного дела суд в первую очередь должен быть независим, беспристрастен, нацелен на достижение объективной истины, оценивать доказательства, формируя своё собственное внутреннее убеждение индивидуально к рассматриваемому делу, сопоставлять и анализировать на основе последнего фактически представленные ему сторонами до-

37 Паркина А.В., Уздимаева Н.И. Правоприменительная ошибка: понятие и признаки. C. 4. URL: https://cyberleninka.ru/article/n/pravoprimenitelnaya-oshibka-ponyatie-i-priznaki 
Злоупотребление правом и судебные ошибки в уголовном судопроизводстве...

казательства» $^{38}$. Между тем, как указывает А.А. Аубакирова, «внутреннее убеждение является продуктом взаимодействия его разума, чувств и воли, это не просто мысль, правильный взгляд, а эмоционально окрашенная идея, внутренняя сила, регулирующая и направляющая человеческое поведение, которая порой может быть ошибочной» ${ }^{39}$.

Исследуя причины возникновения судебных ошибок, можно разделить их на объективные и субъективные. К объективным причинам Н.А. Батурина относит экономические, политические, социальные, исторические, законодательные и организационные. ${ }^{40} \mathrm{~B}$ качестве одной из объективных причин В.И. Власов указывает на большую нагрузку правоприменителя ${ }^{41}$. По мнению И.А. Остапенко, такими причинами являются нестабильность законодательства и несовершенство построения организации судопроизводства ${ }^{42}$. Полагаем, что дополнительно к перечисленным причинам можно отнести дефекты законодательной техники.

Мы считаем возможным не согласиться с позицией С.С. Безрукова, указывающего в качестве объективной причины возникновения судебных ошибок использование в уголовном законодательстве оценочных терминов, предоставляющих правоприменителю относительную свободу принятия решений ${ }^{43}$. Наличие относительно определённых правовых норм и оценочных понятий в уголовнопроцессуальном законодательстве России является обязательным, обусловливает возможность установления истины по делу и направлено на эффективность и справедливость судебного разбирательства. Последняя является непременным условием для соблюдения ст. 6 УПК РФ о назначении судопроизводства. Применительно к доводам автора, полагаем, что более правильным в этом ключе было бы говорить о неправильном субъективном применении относительно определённых правовых норм и использовании оценочных понятий в уголовном судопроизводстве, что относится, по нашему мнению, к субъективным причинам возникновения судебных ошибок.

К субъективным причинам возникновения судебных ошибок относят достаточной широкий спектр свойств, имеющих непосредственное отношение к личности правоприменителя. В частности, Б. Колб относит к субъективным причинам судебных ошибок «психические свойства личности и особенности его нервной системы; низкую профессиональную подготовку и незначительный опыт работы» ${ }^{44}$. По мнению В.И. Власова, к ним относится отсутствие должностных моральных, а также некоторых специальных качеств, их недостаточное развитие ${ }^{45}$. Однако нельзя согласиться с мнением Н.Н. Вопленко, который относит к субъективным причинам возникновения судебных ошибок односторонность и неполноту доказательств ${ }^{46}$, поскольку не всегда этот недостаток доказательственного материала можно преодолеть посредством процессуальной судебной деятельности самого правоприменителя. В частности, при рассмотрении уголовных дел в особом порядке судья работает с материалами уголовного дела, которые сформированы органом предварительного следствия односторонне и неполно. В таком уголовном деле, как правило, отсутствуют материалы, которые могут вызвать сомнения в событии преступления и причастности к нему подсудимого. Глава 40 УПК РФ не допускает проведения судебно-следственных действий, направленных на выяснение обстоятельств, имеющих отношение к событию преступления и причастности к нему обвиняемого, в связи с чем у суда отсутствует возможность самостоятельно без изменения процедуры судопроизводства провести исследо-

\footnotetext{
${ }^{38}$ Азаров В.А., Беккер Т.А. Установление истины как основа предотвращения судебных ошибок в уголовном судопроизводстве. М.: Юрлитинформ, 2019.С. 40.

39 Аубакирова А.А. Следственные и экспертные ошибки при формировании внутреннего убеждения: автореф. дис. ... докт. юрид. наук. Челябинск, 2010. С. 4.

${ }^{40}$ Батурина Н.А. Причины судебных ошибок и процессуальные средства их предупреждения в гражданском судопроизводстве: дис. канд. юрид.наук. Саратов, 2010. С. 12.

${ }^{41}$ Власов В.И. Расследование преступлений, проблемы качества. Саратов. 1988. С. 97.

${ }^{42}$ Остапенко И.А. Причины возникновения судебных ошибок // Вестник Владимирского юрид. ин-та. 2007. № 4

(5). C. 227.

${ }^{43}$ Безруков С.С. Оценочные понятия и термины в уголовно-процессуальном законодательстве России. Омск, 2003. C. 4

${ }^{44}$ Колб Б. Природа и причины судебных ошибок // Законность. 1997. № 3. С. $23,47$.

${ }^{45}$ Власов В.И. Расследования преступлений: проблемы качества. Саратов, 1988. С. 98.

${ }^{46}$ Вопленко Н.Н. Причины ошибок в правоприменении (опыт конкретно-социологического изучения) // Советское государство и право. 1982. № 4. С. 104.
} 
вание и проверку имеющихся в материалах дела доказательств виновности подсудимого и прийти к независимым выводам по делу на основе внутреннего убеждения. Именно невозможность проведения судьёй необходимых ему для принятия взвешенного и справедливого решения по делу процессуальных действий может стать объективной причиной совершения им судебной ошибки.

Одной из целей введения в отечественное уголовно-процессуальное законодательство упрощённых процедур судопроизводства было повышение качества рассмотрения сложных уголовных дел и снижение количества ошибок при их рассмотрении. Законодатель полагал, что введение в УПК РФ гл. 40 позволит снизить нагрузку на судей за счёт отсутствия по таким делам спора о вине, что позволит освободить время для судебных разбирательств по делам, где отсутствует однозначность и имеется спор о событии преступления и вины в нём подсудимого. Это, по мнению законодателя, должно было способствовать высвобождению у судей дополнительного времени для более качественного рассмотрения сложных уголовных дел, что в свою очередь снизит по таким делам риск судебной ошибки. Категория «судебная ошибка» неоднократно являлась предметом исследования в уголовном судопроизводстве, но её изучение ограничивалось общими условиями судебного разбирательства. Применительно к особому порядку судебного разбирательства указанная категория не анализировалась. Однако практика применения гл. 40 УПК РФ показала, что особый порядок постановления приговора сам стал причиной совершения судебных ошибок, природа которых обусловлена особенностями данной формы судопроизводства. Законодатель впервые выбрал путь упрощения и оптимизации процедуры уголовного судопроизводства, а также предоставил сторонам право свободно распоряжаться своими процессуальными правами, поставив тем самым результат судебного разбирательства в зависимость от позиции, добросовестности и волеизъявления сторон по делу. Между тем главной особенностью особого порядка судопроизводства является существенное сужение полномочий судьи как главного участника судопроизводства и сужение пределов его процессуальной деятельности по усмотрению. Практически все нормы гл. 40 УПК РФ применительно к процессуальной деятельности судьи сформулированы императивно, а используемая законодателем лингвистическая конструкция «вправе», при соотношении её с другими корреспондирующими с ней нормами полностью нивелируется.

Среди прочих возможных причин судебных ошибок при рассмотрении уголовных дел в порядке гл. 40 УПК РФ считаем необходимым обратить внимание на следующие три:

1) объективный дефицит достоверной информации при постановлении приговора в особом порядке;

2) внутренние противоречия гл. 40 УПК РФ и её несоответствие основным принципам и условиям уголовного судопроизводства;

3) ошибка морального выбора;

4) ошибка в оценке доказательств.

Необходимо отметить, что, судебные ошибки, совершённые вследствие объективного дефицита информации, всегда являются вторичными по отношению к ранее совершённым следственным ошибкам либо разного рода злоупотреблениям. В рамках предварительного расследования при формировании уголовного дела, в котором уже имеются согласие обвиняемого с предъявленным ему обвинением и его ходатайство о рассмотрении уголовного дела в особом порядке, качество следственной работы сразу ухудшается, поскольку такое дело фактически переходит в поточное производство. Мотивы и цели обвиняемого, почему именно он согласился с предъявленным ему обвинением, уже мало кого интересуют. Материалы уголовного дела формируются таким образом, чтобы избежать попадания в них доказательств, позволяющих впоследствии усомниться в виновности обвиняемого. Однако даже если впоследствии в рамках рассмотрения уголовного дела в суде возникает необходимость исследования фактических обстоятельств в силу следующего:

- прекращение судом особого порядка рассмотрения уголовного дела и переход, по собственному усмотрению, в общий порядок судебного разбирательства вопреки позиции стороны обвинения и защиты, нарушает право обвиняемого на защиту в той части, что лишает его права на льготный вид и размер наказания, который предусмотрен за вменяемое ему преступление с учётом ч. 7 ст. 316 УПК РФ;

- органами предварительного расследования дана неверная квалификация преступления (например, не учтены отягчающие обстоятельства). Однако переквалифицировать преступное деяние без исследования в суде фактических обстоятельств, имеющих непосредственное отношение к событию преступления, невозможно в силу ч. 5 ст. 316 УПК РФ; 
Злоупотребление правом и судебные ошибки в уголовном судопроизводстве...

- восполнить такие пробелы в материалах уголовного дела практически уже невозможно.

При таких обстоятельствах судья лишен возможности совершения необходимых ему для достижения целей правосудия процессуальных действий. У него отсутствует для этого правовой инструментарий. Это является объективным препятствием для постановления законного, обоснованного и справедливого приговора, способствующим совершению им как процессуальных, так и фактических ошибок.

Глава 40 УПК РФ содержит внутренние противоречия, которые вводят правоприменителя в заблуждение относительно объема его полномочий и широты судебного усмотрения. В частности, это касается объёма прав и обязанностей суда при исследовании и оценке доказательств по делу с целью постановления приговора по нему.

1. Если обратиться к наименованию разд. Х УПК РФ «Особый порядок судебного разбирательства», в состав которого входит гл. 40 , то из его буквального толкования становится очевидным, что при особом порядке судебное разбирательство, пусть и с особенностями, но проводится. Между тем ч. 2 ст. 314 УПК РФ уже содержит утверждение о том, что «... суд вправе постановить приговор без проведения судебного разбирательства...». Часть 1 ст. 316 УПК РФ содержит следующую формулировку: «судебное заседание по ходатайству подсудимого о постановлении приговора без проведения судебного разбирательства...». Таким образом, законодатель, декларируя в названии соответствующего раздела проведение судебного разбирательства с изъятиями, предусмотренными настоящим разделом, в самих правовых нормах гл. 40, которые составляют указанный раздел, прямо запрещает проводить какое-либо судебное разбирательство. Личные характеристики подсудимого и обстоятельства, смягчающие либо отягчающие наказания, не всегда относятся к событию преступления, в связи с чем принимать их исследование за судебное разбирательство нельзя.

2. Часть 5 ст. 316 УПК РФ устанавливает, что судья не проводит в общем порядке исследование и оценку доказательств. По делу могут быть исследованы обстоятельства, характеризующие личность подсудимого, и обстоятельства, смягчающие или отягчающие наказание. Однако, уже в ч. 7 указанной статьи законодатель требует от судьи проверить обоснованность обвинения и подтверждается ли оно собранными по делу доказательствами. Указанная правовая конструкция порождает два варианта судебных ошибок:

- относительно возможности совершения судьёй тех или иных процессуальных действий, направленных на установление фактов, подтверждающих либо опровергающих обоснованность обвинения;

- понуждает судью постановить приговор, имитируя процессуальную деятельность по осуществлению правосудия. Конструкция гл. 40 УПК РФ фактически перекладывает моральную ответственность за постановленный судом приговор на орган предварительного расследования и самого подсудимого, поскольку возможность перепроверить качество и добросовестность работы следователя при рассмотрении уголовного дела в особом порядке у суда отсутствует, а проверка мотивов и добровольности согласия обвиняемого с предъявленным ему обвинением представляет собой формальный ритуал. Кроме того, процессуальный статус действия, которое проводит суд в порядке ч. 4 ст. 316 УПК РФ, вызывает недоумение, поскольку действующему УПК РФ известна только одна процессуальная форма такого судебно-следственного действия - допрос подсудимого в порядке ст. 275 УПК РФ. Статус опроса подсудимого, о котором идёт речь в ч. 4 ст. 316 УПК РФ, а также отражение в мотивировочной части приговора суда его результатов, вызывает сомнения.

Ошибка морального выбора как некий обобщённый термин представляет собой ту грань между судебной ошибкой и злоупотреблением со стороны суда при осуществлении правосудия, которая непосредственно связана с внутренним убеждением правоприменителя и необходимостью совершения им определённого выбора. Именно от мотивов этого выбора (в случае, если он будет неверным) и зависит, будет ли являться это решение судебной ошибкой либо злоупотреблением.

Формально, уголовно-процессуальный закон предоставляет судье право самостоятельно выбрать, в каком порядке ему рассматривать уголовное дело. Критериями выбора являются соблюдение условий ч. 1 и 2 ст. 314 УПК РФ и обоснованность и доказанность обвинения, с которым согласился обвиняемый.

Закон предоставил судье следующие средства проверки перечисленных критериев: опосредованное изучение материалов уголовного дела до начала проведения судебного заседания и непосред- 
ственное исследование обстоятельств, характеризующих личность подсудимого, и обстоятельств, смягчающих и отягчающих наказание.

Однако годность перечисленных средств применительно к проверке указанных критериев вызывает обоснованные сомнения.

Объективный дефицит информации по уголовному делу формально не является основанием для перехода в общий порядок рассмотрения уголовного дела. Не является он и основанием возвращения его прокурору в порядке ст. 237 УК РФ. Суд вынужден постановить приговор на основании тех доказательств вины подсудимого, которые перечислены в обвинительном заключении / постановлении. Данное обстоятельство не способствует выполнению судьёй ст. 6 УПК РФ. Даже обладая должным уровнем критичности и будучи свободным от предубеждения виновности подсудимого после ознакомления с материалами уголовного дела, судье весьма сложно даже для себя обосновать необходимость перехода в общий порядок судебного разбирательства. Такое решение не только влияет на объём прав подсудимого, но и существенно увеличивает нагрузку на суд и государственного обвинителя, в связи с чем для его принятия у судьи должны сформироваться исключительные сомнения в виновности подсудимого уже на стадии опосредованного изучения материалов уголовного дела вопреки имеющемуся в нём ходатайстве подсудимого о рассмотрении дела в особом порядке. Таким образом, судья оказывается перед моральным выбором формы судопроизводства по уголовному делу, при этом объективно наименьшими издержками будет обладать решение о рассмотрении его в особом порядке.

Речь об ошибке морального выбора может идти только в том случае, если суд находится в добросовестном заблуждении относительно виновности подсудимого, а также полноты и качества доказательственной базы. Если у судьи действительно имеются основания полагать, что есть необходимость более тщательной проверки имеющихся в деле доказательств, либо имеет место самооговор, либо есть сомнения в психическом здоровье подсудимого, однако суд, формально не нарушая букву закона, рассматривает уголовное дело в особом порядке, постановляя по нему обвинительный приговор, здесь имеет место злоупотребление. Мотивы в данном случае могут быть разными, но все они обусловлены личной целесообразностью правоприменителя: повышением эффективности процесса судопроизводства путём снижения издержек, снижением риска отмены приговора, психологическим перекладыванием ответственности за своё решение на орган предварительного расследования и самого подсудимого, восприятием судебного следствия как ненужного рудимента, усложняющего работу судей. Наиболее ярким примером такой формы деформации судебного мышления служит частное постановление судьи Красноперекопского районного суда гор. Ярославля А.В. Курапина от 17.10.2019 г. по уголовному делу № 1-154/2019 в адрес Генерального Прокурора РФ Ю.Я. Чайки ${ }^{47}$ о необходимости прекращения беспричинного препятствования прокуроров особому порядку рассмотрения уголовных дел, предусмотренному гл. 40 УПК РФ.

Ошибка морального выбора схожа со злоупотреблением ещё и в том, что она не всегда обусловлена нарушением правовых норм и представляет собой поиск возможности внешне проявить определённый набор моральных ценностей в отсутствие риска отмены вынесенного приговора. При поиске таких компромиссов судья попадает в условия нормативного конфликта, который ему необходимо разрешить, не задев интересов единственного участника процесса, с которым у него возможна коллаборация, а именно, государственного обвинителя. При отсутствии доброй воли на принятие сложных и рисковых процессуальных решений, судья «выбирает самую "безобидную" из доступных ему "бесплатных" санкций, т.е. ту опцию, которая, с его точки зрения, принесёт обвиняемому меньше всего вреда» ${ }^{48}$. Применительно к особому порядку судебного разбирательства, это может быть минимально возможный размер назначения наказания. Это обстоятельство, имеющее исключительно утилитарное объяснение, опровергает точку зрения о высоком гуманитарном стандарте российских судей.

Как справедливо отмечает Т.А. Беккер, «внутреннее убеждение не остаётся неизменным, его корректирует каждое последующее доказательство (выслушивание и проверка показаний свидетелей и

\footnotetext{
${ }^{47}$ Указанное частное постановление в настоящее время отменено.

${ }^{48}$ Панеях Э. Практическая логика принятия судебных решений: дискреция под давлением и компромиссы за счёт подсудимого. Как судьи принимают решения: эмпирические исследования права / под ред. В.В. Волкова, М.: Статут, 2012. С. 127.
} 
Злоупотребление правом и судебные ошибки в уголовном судопроизводстве...

подсудимых, исследование вещественных и письменных доказательств, устранение возникших неясностей и противоречий в доказательствах, анализ и синтез воспринятых и проверенных доказательств)» ${ }^{49}$. Ошибка в оценке доказательств является, на наш взгляд, наиболее распространённым видом судебной ошибки при постановлении приговора по существу. Неверная интерпретация одного доказательства может повлечь за собой неверную оценку всех последующих доказательств и стать причиной последующей судебной ошибки. По верному мнению А. Косого, «в момент первого ознакомления судьи с материалами уголовного дела (на этапе предварительного изучения дела судьёй), у него складывается первое впечатление, которое оставляет в уме определённый отпечаток, воздействующий на всё последующее рассмотрение дела до тех пор, пока совокупность факторов, накопленных знаний об обстоятельствах дела не вызовет в сознании судьи достаточно определённый образ искомого» ${ }^{50}$. Однако при особом порядке судебного разбирательства это первичное впечатление становится единственным, на основании которого суд должен разрешить уголовно-правовой конфликт по существу и постановить по делу обвинительный приговор. При особом порядке постановления приговора не происходит трансформации оценки исследованных доказательств во внутреннее убеждение, поскольку сам процесс их исследования ограничивается изучением материалов уголовного дела при подготовке дела к судебному заседанию, то есть первичным ознакомлением. Последующего процесса сравнения, проверки либо получения новых доказательств, которые могут подтвердить либо опровергнуть уже имеющиеся в материалах дела доказательств, законом не предусмотрено. У судьи формально отсутствует возможность проверить свое чувство убеждённости относительно изученных материалов уголовного дела, рассмотрение которого предполагается в порядке гл. 40 УПК РФ, поскольку исследование доказательств в общем порядке в таком судебном заседании не предусмотрено согласно ч. 5 ст. 316 УПК РФ. Это обстоятельство является основной причиной ошибок при оценке доказательств по такой категории дел. Отсюда можно сделать вывод о том, что процесс формирования внутреннего убеждения по таким делам заканчивается моментом принятия судьёй решения о назначении уголовного дела к рассмотрению в судебном заседании в особом порядке судебного разбирательства.

Очевидно, что все перечисленные выше причины судебных ошибок и злоупотреблений, в том числе и субъективных, обусловлены отсутствием у судьи возможности при рассмотрении уголовного дела в особом порядке в случае возникновения у него сомнений относительно материалов уголовного дела, достоверности доказательств, самого события преступления либо отношения к нему подсудимого, а также мотивов и целей заявления последним ходатайства о рассмотрении уголовного дела в особом порядке, устранить эти сомнения, не изменяя процедуры судопроизводства.

Поступила в редакцию 12.04.2021

Машинникова Наталья Олеговна, аспирант кафедры уголовного процесса

и правоохранительной деятельности

ФГБОУ ВО «Удмуртский государственный университет»

426034, Россия, г. Ижевск, ул. Университетская, 1

E-mail: n-alico@mail.ru

\section{N.O. Mashinnikova \\ ABUSE OF THE RIGHT AND JUDICIAL ERRORS IN THE EXERCISE OF DISCRETION BY THE JUDGE IN THE CONSIDERATION OF CRIMINAL CASES WITH THE CONSENT OF THE ACCUSED WITH THE CHARGE BROUGHT AGAINST HIM}

DOI: $10.35634 / 2412-9593-2021-31-3-459-472$

The article examines the categories of "abuse of law" and" miscarriage of justice", as well as the factors contributing to their occurrence, reveals the mechanism of occurrence of miscarriages of justice, the sources and causes of their occurrence. The author substantiates the claim that the defect of interest, as an aspect of law enforcement, causes the occur-

\footnotetext{
${ }^{49}$ Беккер Т.А. Установление истины как основа предотвращения судебных ошибок в уголовном судопроизводстве: дис. канд.юрид.наук.. Омск, 2016. С. 118.

${ }^{50}$ Косой В.А. Внутреннее убеждение судьи // Современное право. 2013. № 4. С. 99.
} 
rence of abuse and can cause a miscarriage of justice. The main characteristics of a miscarriage of justice, as well as the signs that distinguish a miscarriage of justice from abuse, are revealed. The definition of "abuse of the right" is given, its properties and features are revealed. The article analyzes the peculiarities of committing judicial errors and abuses under a special procedure of judicial proceedings.

Keywords: special procedure of judicial proceedings, judicial discretion, internal conviction, truth, judicial error, abuse of law, interest, criminal proceedings, Chapter 40 of the Code of Criminal Procedure of the Russian Federation.

Received 12.04.2021

Mashinnikova N.O., postgraduate student of the Department of Criminal Procedure and Law Enforcement Udmurt State University

Universitetskaya st., 1/4, Izhevsk, Russia, 426034

E-mail: n-alico@mail.ru 